\title{
FORMALIZATION OF INFORMAL CARE IN THE NETHERLANDS: COST CONTAINMENT OR GENDERED COST REDISTRIBUTION?
}

\section{THIJS VAN DEN BROEK}

Erasmus University Rotterdam, Department of Sociology, PO Box 1738, 3000 DR Rotterdam, The Netherlands

Published as: Van den Broek, T. (2013). Formalization of informal care in the Netherlands: Cost containment or gendered cost redistribution? International Journal of Feminist Approaches to Bioethics, 6, 185-193.

URL Original article:

http://www.jstor.org/stable/10.2979/intjfemappbio.6.2.185?seq=1\#page_scan_tab_contents 


\begin{abstract}
In order to contain public care expenditure, policy makers in the Netherlands have over the last decades formulated in ever more stringent ways what ought to be expected from spouses, partners and family members with regard to care for dependent relatives. The current Dutch coalition cabinet plans to shift the principal responsibility for non-medical care, including demanding forms of care such as long-term personal care, to individuals and families. I argue that these policy developments imply cost redistribution rather than cost containment and that this redistribution is disadvantageous for women.
\end{abstract}

Keywords: long-term care; informal care; population ageing; gender 
Population aging and the associated greater need for long-term care have made policy makers in developed countries reconsider welfare state arrangements (Alcock and Craig 2009; Pavolini and Ranci 2008). The Netherlands are no exception. In order to contain public-care expenditure, Dutch policy-makers have over the last decades formulated in ever more stringent ways what ought to be expected from spouses, partners and family members with regard to care for dependent relatives (Morée, Van der Zee, and Struijs 2007). Eventually, this process, which has been labeled formalization of informal care, culminated in the allocation of the principal responsibility for the provision of lighter forms of care to the family instead of the state. Currently, a next step in this process is being considered: the principal responsibility for nonmedical care, including relatively demanding forms such as long-term personal care, may be shifted to the family. In this commentary I argue that formalization of informal care redistributes rather than contains costs and that this redistribution is disadvantageous for women.

\section{The Netherlands: Formalization of informal care}

In many developed countries, long-term care responsibilities are shifted to the family, with state welfare more and more being framed as a last resort for those most in need (Alcock and Craig 2009). Along with the Nordic countries, the Netherlands are among the states in Europe where eldercare is most highly defamilialized, that is, where frail elderly are least dependent from family support to address their needs (Saraceno and Keck 2011). However, Dutch policy-makers have made the substantial increase of the number of informal caregivers a formal policy goal (Mot 2010). The pressure on family members to provide care to dependent relatives has become greater over the last decades (Morée, Van der Zee, and Struijs 2007).

In the post-war era, policy arrangements in the Netherlands were aimed at increasing the independence of people in need of care, which led to a great increase in publically provided 
long-term care. Gradually, however, this care ideal shifted and policy makers increasingly underlined the responsibilities of individuals and their families. Since the 1990s, the state's expectations towards the spouses, partners, and family members of dependent persons have become explicit in ever more stringent ways (Morée, Van der Zee, and Struijs 2007). Eventually, this process led to the labeling of certain forms of care as usual care (Dutch: gebruikelijke zorg).

The usual care concept was launched in 2003 and subsequently modified and formalized in a protocol, with the explicit intention to limit the formal support prescribed and thereby to contain costs (Morée, Van der Zee, and Struijs 2007). Usual care is defined as "the normal, daily care that nuclear family members or other people who share a household can be expected to provide to one another" (CIZ 2012, 9, author's translation). The usual care protocol is crucial in determining entitlement to specific benefits under the Exceptional Medical Expenses Act (Dutch: Algemene Wet Bijzondere Ziektekosten, $A W B Z$ ), which aims to provide a general insurance covering the Dutch population against exceptional health care needs. The protocol applies to AWBZ-provision of social participation support (e.g., help with mobility issues that would hamper family visits) and personal care (e.g., help with washing and dressing), insofar assessment officers do not expect dependency to last for more than three months. Therefore, dependent people sharing a household are typically not eligible for public provision of these forms of care. Since these forms of care are considered relatively undemanding, physically and mentally capable household members are expected to step up instead. Municipalities entrusted with the execution of the Social Support Act (Dutch: Wet Maatschappelijke Ondersteuning, $W M O)$ - which aims to offer support to people who need it to sustain their independence and participation in society - mostly use a similar protocol for determining entitlement to publically provided domestic help (Tuynman and Marangos 2010). 
Largely in line with recent advisory reports by the Council for Public Health and Health Care (RVZ 2012) and the Social and Economic Council of the Netherlands (SER 2012), the current coalition cabinet formed by conservative-liberals and social-democrats intends to further retrench public long-term care arrangements. Plans are to focus public long-term arrangements more strictly on medical care, while shifting the principal responsibility for non-medical care to individuals and their families. Publically provided non-medical care is seen as a last safety net, to which only those who cannot afford paid alternatives and lack a network of potential informal caregivers should be entitled (VVD - PvdA 2012). This shift could be perceived as a next step in the formalization process of informal care, as it applies to forms of care which are more demanding than the forms of care to which the usual care label currently applies, that is, longterm personal care.

\section{Gendered consequences}

Care policies, though typically de jure gender-neutral, are rarely de facto gender-neutral (Saraceno and Keck 2011). Policies determine to what extent care is defamilialized. Rudimentary public care arrangements intensify demands on family caregivers, while generous public care arrangements relieve family caregivers. This is particularly the case in families where the financial means to afford paid alternatives for family care are lacking. Partners and adult children are the main providers of family care to the frail old (Cantor 1979; Cloïn, et al. 2011; Dykstra 2007; Wolff and Kasper 2006). This provision of family care is highly gendered. Daughters and daughters-in-law provide more care to their dependent older parents than sons (Haberkern and Szydlik 2010; Ogg and Renaut 2006; Schmid, Brandt, and Haberkern 2012) and wives provide more care to dependent spouses than husbands (Noël-Miller 2010; Spitze and Ward 2000). It is generally established that husbands are less likely than wives to serve as primary caregiver 
(Allen, Goldschneider and Ciambrone 1999; Lima, et al. 2008) and that they have a stronger tendency than wives to share care tasks with other potential caregivers (Antonucci and Akiyama 1987; Feld, Dunkle, and Schroepfer 2005; Feld, Dunkle, et al. 2010). Since family caregivers are mainly women, the design and generosity of public care arrangements have highly gendered effects (Saraceno and Keck 2011). For instance, research has shown that poorly available social services push daughters, but not sons, to provide intensive support to dependent parents (Schmid, Brandt and Haberkern 2012), arguably because inaccessibility of public care reinforces women's perception of themselves as a key locus of care (Aronson 1990).

The reallocation of care responsibilities to families, and effectively to women within them, is not without consequences. While providing informal care can entail positive outcomes, such as a sense of satisfaction or learning new skills (Cloïn et al. 2011; Cohen, Colantonio, and Vernich 2002; Reinhard, Levine, and Samis 2012), it is also associated with a range of economic and non-economic costs (Fast, Williamson and Keating 1999). For employed women providing informal care is associated with lower wages (Heitmueller and Inglis 2007) and women with paid work who start giving care are more likely than non-caring women to reduce employment hours or to leave their job altogether (Berecki-Gisolf et al. 2008; Pavalko and Artis 1997). The disadvantageous labor market trajectories associated with caregiving may have unwelcome consequences beyond the working age, in the form of lower pension benefits. This is particularly likely when pension claims are tightly linked to contributions and acknowledgement of care work in the public pension scheme is absent, as is the case in the Netherlands (Saraceno and Keck 2011).

Retrenchment of public long-term care arrangements, as planned in the Netherlands, may reinforce the negative impact of informal caregiving on women's employment. In Europe, the 
negative association between informal caregiving and women's employment is stronger in countries with rudimentary public long-term care arrangements than in countries with more generous public long-term care arrangements (Kotsadam 2011). Kotsadam (2011) argues that this may be related to the relatively low degree of coercion in the latter countries for family members to take on the caring role. Family members may feel less forced to provide care and accept the associated employment trade-offs when public care is available for a dependent relative.

The trade-offs of providing informal care are not limited to employment and pensions. Caregiving is also associated with stress and declines in mental and physical health (Aggar, Ronaldson and Cameron 2011; Coe and Van Houtven 2009; Reinhard, Levine, and Samis 2012; Schulz et al. 2001). Many informal caregivers feel overburdened (Cloïn et al. 2011). While longitudinal studies on the impact of similar social policy changes on the quality of life outcomes of family caregiving are to my knowledge inexistent, it can be expected that the planned longterm care reforms in the Netherlands will aggravate the adverse implications of providing care for family caregivers. First of all, the principal responsibility for demanding forms of nonmedical care, such as long-term personal care, will be reallocated to the family. Research has shown that the adverse quality of life effects of caregiving on family caregivers are particularly strong when the provided care is complex and long-lasting (Cloïn et al. 2011; Coe and Van Houtven 2009). Additionally, diminishing public long-term care generosity increases the degree of coercion in family members' caring decision (cf. Kotsadam 2011). Care reluctance is relatively great for caregivers who feel that they did not enter the caring position by choice (Burridge, Winch, and Clavarino 2007), and those who resent having to care for a frail older 
relative report higher levels of anxiety and depressive symptoms than those who are at peace with their caring role (Aggar, Ronaldson, and Cameron 2011).

The reallocation of responsibilities for a wide range of non-medical care, including longterm personal care, to families may not just be disadvantageous for women as providers of care, but also as care recipients. When people are in need of long-term personal care they tend to prefer public care arrangements over informal care (Wielink, Huijsman, and McDonnell 1997). Those who receive informal care often experience feelings of loss of autonomy and of being a burden (Cahill et al. 2009; Fast, Williamson, and Keating 1999). Particularly for women this may create tension, as it has been argued that the feeling of being a burden clashes with the cultural imperative women experience to be self-reliant, undemanding, and self-possessed (Aronson 1990).

With regard to the usual care protocol, one could further question whether informal care provided by a co-residing spouse or partner meets an impaired older adult's care needs to the same extent as the public care available for those who are not part of a shared household. The usual care protocol implicitly assumes that the bare presence of a healthy co-residing spouse or partner is a sufficient condition for access to adequate informal care. Not every healthy spouse or partner is equally able or willing to provide care though. Particularly women may not receive adequate spousal care or partner care when public care is not available for them. Research has shown that husbands receive more hours of spousal care after a decline in the ability to perform activities of daily living than wives (Noël-Miller 2010).

\section{Cost containment or cost redistribution?}

Dutch policy-makers committed themselves to contain the costs of public long-term care to a level that is acceptable to society (Mot 2010). In line with this, the process of formalization 
of informal care has been largely economically motivated (Morée, Van der Zee, and Struijs 2007), as are current plans for a further going shift of the principal responsibility for non-medical care to individuals and their families (VVD - PvdA 2012). I do not dispute that shifting care responsibilities from the state to the family is an effective measure to contain public care costs. However, it obviously comes with an ever more stringent demand on, mostly female, family members to provide care, and it would be a mistake to perceive family care as cost-free (Fast, Williamson, and Keating 1999). The ongoing retrenchment of public long-term care arrangements is likely to go hand in hand with an increase in economic and non-economic costs for caregivers and care recipients. In this commentary I have argued that it can be expected that women will carry the lion's share of these costs. Therefore, the ongoing formalization of informal care in the Netherlands primarily means redistributing rather than containing costs.

In an earlier essay on the sharing of long-term care responsibilities in this journal, Tong (2009) has argued that a state of affairs "which on the surface appears to demand more sacrifice from women than men, would seem to be a priority for countries that do not want to disproportionally burden their women with society's caregiving work" (18). However, considerations regarding the gendered consequences of the ongoing formalization of informal care are not prominent in the current policy debate surrounding long-term care in the Netherlands (Mot 2010). The strong focus on public expenditure in the current policy debate in the Netherlands combined with the fact that the gendered redistribution effects of the formalization of informal care are being overlooked justifies concerns that the future of Dutch long-term care may very well turn out unfavorable for women. 


\section{References}

Aggar, Christina, Susan Ronaldson, and Ian D. Cameron. 2011. Self-esteem in carers of frail older people: Resentment predicts anxiety and depression. Aging \& Mental Health 15 (6): $671-78$.

Alcock, Pete, and Gary Craig. 2009. The international context. In International Social Policy: Welfare Regimes in the Developed World, ed. Pete Alcock and Gary Craig. Houndmills, Basingstoke, Hampshire: Palgrave Macmillan.

Allen, Susan M., Frances Goldschneider, and Desirée A. Ciambrone. 1999. Gender roles, marital intimacy, and nomination of spouse as primary caregiver. The Gerontologist 39 (2): 15058.

Antonucci, Toni C., and Hiroko Akiyama. 1987. An examination of sex differences in social support among older men and women. Sex Roles 17 (11-12): 737-49.

Aronson, Jane. 1990. Women's perspectives on informal care of the elderly: Public ideology and personal experience of giving and receiving care. Ageing and Society 10 (1): 61-84.

Berecki-Gisolf, Janneke, Jayne Lucke, Richard Hockey, and Annette Dobson. 2008. Transitions into informal caregiving and out of paid employment of women in their 50s. Social Science \& Medicine 67 (1): 122-27.

Burridge, Letitia, Sarah Winch, and Alexandra Clavarino. 2007. Reluctance to care: A systematic review and development of a conceptual framework. Cancer Nursing 30 (2): E9-E19.

Cahill, Eileen, Lisa M. Lewis, Frances K. Barg, and Hillary R. Bogner. 2009. "You don't want to burden them": Older adults' views on family involvement in care. Journal of Family Nursing 15 (3): 295-317. 
Cantor, Marjorie H. 1979. Neighbors and friends: An overlooked resource in the informal support system. Research on Aging 1 (4): 434-63.

CIZ. 2012. CIZ indicatiewijzer. Toelichting op beleidsregels indicatiestelling AWBZ 2012 zoals vastgesteld door het ministerie van VWS. Driebergen: Centrum Indicatiestelling Zorg.

Cloïn, Mariëlle, Freek Buckx, Alice De Boer, and Debbie Oudijk. 2011. Zorgen voor elkaar. In De sociale staat van Nederland 2011, ed. Rob Bijl, Jeroen Boelhouwer, Mariëlle Cloïn and Evert Pommer. The Hague: SCP The Netherlands Institute for Social Research.

Coe, Norma B., and Courtney Harold Van Houtven. 2009. Caring for mom and neglecting yourself? The health effects of caring for an elderly parent. Health Economics 18 (9): 991-1010.

Cohen, Carole A., Angela Colantonio, and Lee Vernich. 2002. Positive aspects of caregiving: Rounding out the caregiver experience. Intergenerational Journal of Geriatric Psychiatry $17(2): 184-88$

Dykstra, Pearl A. 2007. Aging and social support. In The Blackwell Encyclopedia of Sociology, ed. George Ritzer. Oxford: Blackwell.

Fast, Janet E., Deanna L. Williamson, and Norah C. Keating. 1999. The hidden costs of informal elder care. Journal of Family and Economic Issues 20 (3): 301-26.

Feld, Sheila, Ruth E. Dunkle, and Tracy Schroepfer. 2005. When do couples expand their ADL caregiver network beyond the marital dyad? Marriage and Family Review 37 (1-2): 2744.

Feld, Sheila, Ruth E. Dunkle, Tracy Schroepfer, and Shen Huei-Wern. 2010. Does gender moderate factors associated with whether spouses are the sole providers of IADL care to their partners? Research on Aging 32 (4): 499-526. 
Haberkern, Klaus, and Marc Szydlik. 2010. State care provision, societal opinion and children's care of older parents in 11 European countries. Ageing and Society 30 (2): 299-323.

Heitmueller, Axel, and Kirsty Inglis. 2007. The earnings of informal carers: Wage differentials and opportunity costs. Journal of Health Economics 26 (4): 821-41.

Kotsadam, Andreas. 2011. Does informal eldercare impede women's employment? The case of European welfare states. Feminist Economics 17 (2): 121-44.

Lima, Julie C., Susan M. Allen, Frances Goldschneider, and Orna Intrator. 2008. Spousal caregiving in late midlife versus older ages: Implications of work and family obligations. The Journals of Gerontology, Series B: Psychological Sciences and Social Sciences 63 (4): $229-38$.

Morée, Marjolein, Boukje Van der Zee, and Alies J. Struijs. 2007. Formalisering van informele zorg. Over de rol van 'gebruikelijke zorg' bij toekenning van professionele zorg. The Hague: CEG The Netherlands Centre for Ethics and Health.

Mot, Esther. 2010. CPB document no. 204. The Dutch system of long-term care. The Hague: CPB Netherlands Bureau for Economic Policy Analysis.

Noël-Miller, Claire. 2010. Longitudinal changes in disabled husbands' and wives' receipt of care. The Gerontologist 50 (5): 681-93.

Ogg, Jim, and Sylvie Renaut. 2006. The support of parents in old age by those born during 1945-1954: a European perspective. Ageing and Society 26 (5): 723-43.

Pavalko, Eliza K., and Julie E. Artis. 1997. Women's caregiving and paid work: Causal relationships in late midlife. The Journals of Gerontology, Series B: Psychological Sciences and Social Sciences 52 (4): 170-79. 
Pavolini, Emmanuele, and Constanzo Ranci. 2008. Restructuring the welfare state: Reforms in long-term care in Western European countries. Journal of European Social Policy 18 (3): 246-59.

Reinhard, Susan C., Carol Levine, and Sarah Samis. 2012. Home alone: Family caregivers providing complex chronic care. Washington, D.C.: AARP Public Policy Institute.

RVZ. 2012. Redzaam ouder. Zorg voor niet-redzame ouderen vraagt om voorzorg door iedereen. The Hague: RVZ Council for Public Health and Health Care.

Saraceno, Chiara, and Wolfgang Keck. 2011. Towards an integrated approach for the analysis of gender equity in policies supporting paid work and care responsibilities. Demographic Research 25: 371-406.

Schmid, Tina, Martina Brandt, and Klaus Haberkern. 2012. Gendered support to older parents: Do welfare states matter? European Journal of Ageing 9 (1): 39-50.

Schulz, Richard, Scott R. Beach, Bonnie Lind, Lynn M. Martire, Bozena Zdaniuk, Calvin Hirsch, Sharon Jackson, and Lynda Burton. 2001. Involvement in caregiving and adjustment to death of a spouse. Findings from the caregiver health effects study. Journal of the American Medical Association 285 (24): 3123-129.

SER. 2012. Advies 12/06. Naar een kwalitatief goede, toegankelijke en betaalbare zorg. The Hague: SER Social and Economic Council of the Netherlands.

Spitze, Glenna, and Russell Ward. 2000. Gender, marriage and expectations for personal care. Research on Aging 22 (5): 451-69.

Tong, Rosemarie. 2009. Long-term care for the elderly worldwide: Whose responsibility is it? International Journal of Feminist Approaches to Bioethics 2 (2): 5-30. 
Tuynman, Mathijs, and Anna Maria Marangos. 2010. Gemeentelijk Wmo-beleid op de negen prestatievelden. In Op weg met de Wmo. Evaluatie van de Wet maatschappelijke ondersteuning 2007-2009, ed. Mirjam De Klerk, Rob Gilsling and Joost Timmermans. The Hague: SCP The Netherlands Institute for Social Research.

VVD - PvdA. 2012. Bruggen slaan. Regeerakkoord VVD - PvdA.

Wielink, Gina, Robbert Huijsman, and Joseph McDonnell. 1997. Preferences for care. A Study of the elders living independently in the Netherlands. Research on Aging 19 (2): 174-98.

Wolff, Jennifer L., and Judith D. Kasper. 2006. Caregivers of frail elders: Updating a national profile. The Gerontologist 46 (3): 344-56. 